\title{
The effectiveness catches of Noctuidae and Elateridae families with pheromone traps in Olsztyn district, in 2011-2012
}

\author{
Efektywność odłowów gatunków z rodzin Noctuidae i Elateridae \\ za pomocą pułapek feromonowych w powiecie olsztyńskim, \\ w latach 2011-2012
}

\author{
Magdalena Pusz ${ }^{1}$, Stanisław Bawoł ${ }^{1}$, Magdalena Jakubowska ${ }^{2}$
}

\begin{abstract}
Summary
The aim of the study was to reduce the occurrence of soil pests in potato and corn, in selected farms in the district of Olsztyn. As part of the project in the years 2011-2012 three field experiments on monitoring the presence of cutworms and wireworms were established according to the methodologies proposed by the Institute of Plant Protection - National Research Institute in the following places: Łęgajny (commune of Barczewo), Barczewko (commune of Barczewo) and Garzewko (commune of Jonkowo) municipality, in the district of Olsztyn. The effectiveness of trapping Elateridae using pheromone traps varied in different localities. In all the positions of catches on specific pheromone species were: Agriotes lineatus L., A. obscurus L. and A. sputator L. The effectiveness and dynamic largely influenced the course of the weather to was. Elateridae population caught using soil sampling in three locations of Warmia and Mazury consisted mostly of larval forms (95.5\%). Wireworms population accounted for four species: Selatosomus aeneus L., Athous subfuscus Müll., Agriotes sputator L. and Dalopius marginatus L.
\end{abstract}

Key words: effectiveness, pheromone traps, cutworms, wireworms, integrated pest management

\section{Streszczenie}

Celem działania doradczego było ograniczenie występowania populacji szkodników glebowych w uprawach ziemniaka i kukurydzy, w wytypowanych gospodarstwach rolnych na terenie powiatu olsztyńskiego. W ramach projektu, w latach 2011-2012 założono trzy doświadczenia polowe, zgodnie z metodykami zaproponowanymi przez Zakład Metod Prognozowania Agrofagów i Ekonomiki Ochrony Roślin przy Instytucie Ochrony Roślin - Państwowym Instytucie Badawczym, w następujących miejscowościach: Łęgajny (gmina Barczewo), Barczewko (gmina Barczewo) oraz Garzewko (gmina Jonkowo), na terenie powiatu olsztyńskiego, gdzie badano obecność rolnic oraz drutowców. Skuteczność odławiania chrząszczy sprężykowatych przy wykorzystaniu pułapek feromonowych w poszczególnych miejscowościach była zróżnicowana. We wszystkich badanych stanowiskach odławiano na swoisty feromon gatunkowy następujące gatunki: Agriotes lineatus L., A. obscurus L. i A. sputator L. Na efektywność odłowu i dynamikę w dużej mierze miał wpływ przebieg warunków pogodowych. Populację Elateridae odłowionych za pomocą odkrywek glebowych, w trzech badanych miejscowościach, na terenie województwa warmińsko-mazurskiego stanowiły głównie formy larwalne (95,5\%). Populację sprężyków stanowiły następujące gatunki: Selatosomus aeneus L., Athous subfuscus Müll., Agriotes sputator L. oraz Dalopius marginatus L.

Słowa kluczowe: efektywność, pułapki feromonowe, rolnice, drutowce, integrowana ochrona roślin

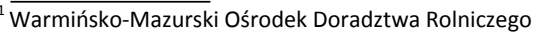
Jagiellońska 91, 10-356 Olsztyn

m.pusz@w-modr.pl

${ }^{2}$ Instytut Ochrony Roślin - Państwowy Instytut Badawczy

Zakład Metod Prognozowania Agrofagów i Ekonomiki Ochrony Roślin

Władysława Węgorka 20, 60-318 Poznań

M.Jakubowska@iorpib.poznan.pl
} 


\section{Wstęp / Introduction}

Podstawową zasadą integrowanej ochrony roślin jest dokładne rozpoznanie czynnika obniżającego poziom i jakość produkcji - plonu oraz określenie właściwego sposobu jego wyeliminowania lub ograniczenia jego liczebności. Zasadniczym staje się poznanie zagrożeń ze strony szkodników, przez monitoring oparty na powszechnych, systematycznych obserwacjach prowadzonych na uprawnych roślinach rolniczych, warzywniczych, sadowniczych i innych (Walczak 2007; Matyjaszczyk i wsp. 2010). Prowadzenie stałych obserwacji nad pojawieniem się i nasileniem zarówno agrofagów, jak i występowania organizmów pożytecznych, jest niezbędne w celu podjęcia właściwej decyzji, co do potrzeby zastosowania odpowiednich metod i środków zwalczania. Aby monitoring przyniósł oczekiwany skutek, niezbędne jest właściwe rozpoznanie organizmu szkodliwego (systematyka, morfologia, biologia, szkodliwość). Prawidłowo prowadzony monitoring oraz właściwa interpretacja zebranych danych (rozpoznanie choroby, szkodnika, czy chwastu) jest ważnym elementem długo- i krótkoterminowego prognozowania pojawienia się organizmów szkodliwych. Poszukiwanie nowych rozwiązań w monitoringu, będącym ważnym elementem w aspekcie integrowanej ochrony roślin w zwalczaniu szkodników glebowych, a w szczególności drutowców i rolnic, jest ciągle tematem aktualnym. Jedną $\mathrm{z}$ możliwości rejestrowania rolnic na plantacjach buraków jest prowadzenie systematycznego monitoringu agrofagów (Małachowska 1987; Piekarczyk i Małachowska 1993; Matyjaszczyk i wsp. 2010; Jakubowska i Ławiński 2011). Umożliwia on jednoczesną obserwację rozwoju szkodnika i pojawienia się jego stadiów szkodliwych, a także pomaga w podjęciu decyzji o ochronie chemicznej. Podobne doświadczenia z wykorzystaniem pułapek feromonowych, można z powodzeniem wykorzystać do monitorowania występowania chrząszczy sprężykowatych. Pułapki feromonowe nie służą do monitorowania larw (Erlichowski 2007, 2009).

Celem pracy było określenie liczebności i składu gatunkowego sprężykowatych (Elateridae) oraz motyli (Lepidoptera) z rodziny sówkowatych (Noctuidae), podrodziny rolnic (Noctuinae) za pomocą pułapek feromonowych w uprawach kukurydzy i ziemniaka. W celach prognozowania długoterminowego analizowano zasiedlenie larw tych szkodników za pomocą odkrywek glebowych.

\section{Materiały i metody / Materials and methods}

Badania monitoringowe dotyczące skuteczności łownej za pomoca pułapek feromonowych prowadzone były w latach 2011-2012 przez Instytut Ochrony Roślin Państwowy Instytut Badawczy w Poznaniu (IOR - PIB) (Zakład Metod Prognozowania Agrofagów i Ekonomiki Ochrony Roślin) i Warmińsko-Mazurski Ośrodek Doradztwa Rolniczego w Olsztynie (W-MODR), w 3 wybranych miejscowościach na plantacjach ziemniaka i kukurydzy. Eksperyment $\mathrm{z}$ badaniem skuteczności łownej pułapek feromonowych dwóch gatunków rolnic, przeprowadzono w miejscowości Garzewko gmina Jonkowo na plantacji kukurydzy, badając dynamikę występowania motyli rolnic. Dla każdego badanego gatunku - Agrotis segetum Den. et Schiff. - rolnica zbożówka i A. exclamationis L. - rolnica czopówka, wykorzystano pułapki feromonowe produkcji polskiej firmy „Medchem” z dyspenserem feromonowym produkcji węgierskiej. Podczas odłowów motyli monitorowano przez cały sezon, od maja do lipca, temperaturę oraz wilgotność względną powietrza. Kontrolę odłowu motyli w pułapkach prowadzono raz w tygodniu, od pierwszej dekady maja do trzeciej dekady lipca odnotowując liczbę złowionych motyli. Dyspenser feromonowy wymieniano co 4-5 tygodni. Przy identyfikacji odławianych gatunków posługiwano się specjalistycznymi kluczami, katalogami oraz zbiorami porównawczymi, korzystano również z internetowej bazy zebranych motyli. Nomenklaturę w obrębie sówkowatych przyjęto według kluczy do oznaczania owadów (Buszko 1956, 1959, 1970; Tykacz 1963; Merzeheevskaya 1989; Fibiger 1997).

Badania z wykorzystaniem skuteczności łownej pułapek feromonowych na obecność chrząszczy sprężykowatych przeprowadzono na terenie następujących miejscowości w województwie warmińsko-mazurskim: Garzewko gmina Jonkowo, Łęgajny i Barczewko gmina Barczewo. Dynamikę występowania chrząszczy gatunków Agriotes lineatus L. - osiewnik rolowiec, A. sputator L. osiewnik skibowiec i A. obscurus L. - osiewnik ciemny, prowadzono od pierwszej dekady maja do trzeciej dekady lipca. Dla każdego badanego gatunku sprężykowatych wykorzystano pułapki feromonowe typu YATLORf zawierające syntetyczny feromon żeński, znajdujący się w kapsule. Feromon wymieniano co miesiąc, a odłowione samce chrząszczy wybierano $\mathrm{z}$ pojemnika pułapki raz na tydzień. Pułapki wystawiono na płaskim terenie na plantacjach kukurydzy i ziemniaków. Zebrane chrząszcze policzono i zidentyfikowano do gatunku przy użyciu specjalistycznych kluczy do oznaczania owadów (Burakowski i wsp. 1985; Boczek 1988; Piekarczyk 1993; Tarnawski 2000).

Zebrane dane meteorologiczne pochodziły ze stacji polowych należących do Centralnego Ośrodka Badania Odmian Roślin Uprawnych (COBORU) w miejscowościach Stupia Wielka i Wrócikowo.

Badania zasiedlenia gleb przez larwy Elateridae oraz gąsienice rolnic i innych szkodników glebowych wykonywano za pomocą analiz glebowych. Materiał biologiczny pozyskiwano dwa razy w sezonie wegetacyjnym, wiosna przed sadzeniem ziemniaków i siewem kukurydzy oraz w sezonie wegetacyjnym w okresie obserwacji owadów dorosłych. W tym celu pobierano próby glebowe wykonując tzw. „odkrywki glebowe” według metodyki opracowanej w IOR - PIB (Piekarczyk 1993). Ziemię pobraną $z$ dołów o wymiarach $25 \times 25 \mathrm{~cm}$ i głębokości $30 \mathrm{~cm}$ przesiewano przez sita. $\mathrm{Na} 1$ ha powierzchni wykonano 32 odkrywki idąc po przekątnej pola. Pozyskaną faunę oznaczono do gatunku według dostępnych kluczy entomologicznych (Rudolph 1974). Następnie, obliczono przeciętne zagęszczenie drutowców i rolnic na $1 \mathrm{~m}^{2}$ według wzoru:

$$
\mathrm{x}=\mathrm{a} / \mathrm{b}
$$

$\mathrm{x}$ - przeciętna liczba drutowców, czy rolnic na $1 \mathrm{~m}^{2}$ gleby, 
a - ogólna liczba odłowionych drutowców, czy rolnic, $\mathrm{b}$ - analizowana gleba $\mathrm{w} \mathrm{m}^{2}$.

Ocena wykonana wiosną odbyła się pod koniec kwietnia przy temperaturze $+10^{\circ} \mathrm{C}$, w momencie stwierdzenia zwiększonej aktywności larw. Jest to metoda bardzo pracochłonna. Obecnie przyjmuje się za Erlichowskim (2007, 2008), że próg szkodliwości dla drutowców w uprawie ziemniaka wynosi od 6 do 11 larw na $\mathrm{m}^{2}$, natomiast duże nasilenie występowania drutowców to powyżej 20 larw na m² (Piekarczyk 1993).

\section{Wyniki i dyskusja / Results and discussion}

\section{Wyniki badań skuteczności łownej pułapek feromonowych do odlowu motyli rolnic $\mathrm{z}$ rodzaju Agrotis sp. i chrząszczy z rodziny sprężykowatych}

Na podstawie dwuletniego monitoringu przeprowadzonego przy użyciu pułapek feromonowych, wykazano obecność dwóch badanych gatunków rolnic w zasiewach kukurydzy. Gatunkami odławianymi były $A$. segetum i A. exclamationis. Na liczebność poszczególnych gatunków motyli z podrodziny Noctuinae istotny wpływ mogły mieć zasiewy innych roślin żywicielskich i chwastów otaczające monitorowane plantacje z kukurydzą. Uzyskane wyniki korespondują $\mathrm{z}$ wynikami innych autorów (Walczak i Jakubowska 2001; Bereś 2011; Jakubowska i Ławiński 2011). Ponadto obserwacje dynamiki lotu A. exclamationis wykazały, że masowo odławiano ten gatunek w czerwcu i lipcu, a poza tym okresem był rzadko spotykanym gatunkiem, co także stwierdził Adamczewski (1992). Prawdopodobnie dlatego odnotowano brak odłowów rolnicy czopówki w roku 2011.

W badaniach własnych stwierdzono, że liczniej odławiano rolnicę zbożówkę niż rolnicę czopówkę. Zróżnicowania liczebności odławianych motyli obu gatunków, można przypuszczalnie upatrywać $\mathrm{w}$ większej tolerancji organizmu tych gatunków na działanie określonych czynników środowiska (Kowalska 1964; Buszko i Nowacki 1990, 1991).

W roku 2011 pierwsze motyle rolnicy zbożówki odłowiono w Garzewku 2 maja (rys. 1). Od maja do końca lipca w sumie odłowiono 12 dorosłych osobników. W roku 2012 pierwsze motyle rolnicy zbożówki w miejscowości Garzewko, na plantacji kukurydzy zostały odłowione 20 maja. W sumie odłowiono od maja do końca lipca 21 sztuk tego gatunku. W przypadku rolnicy czopówki pierwsze naloty motyli obserwowano od 10 lipca. Łącznie odłowiono 18 sztuk dorosłych osobników (rys. 1). Zaobserwowano dwa maksima lotu motyli u obu badanych gatunków. Dla rolnicy zbożówki szczyt lotu owadów dorosłych przypadł na 28 maja i 25 czerwca, a dla rolnicy czopówki na 9 i 23 lipca. W badaniach Jakubowskiej (2008, 2009), w uprawach buraka cukrowego również obserwowano dwa szczyty odłowów motyli dla gatunku rolnicy zbożówki.

Wykorzystując omawianą metodę można w prosty sposób monitorować liczebność owadów dorosłych rolnic i w precyzyjny sposób wyznaczyć najbardziej optymalny termin zwalczania szkodników.
Skuteczność odławiania chrząszczy sprężykowatych przy wykorzystaniu pułapek feromonowych w poszczególnych miejscowościach była zróżnicowana. $\mathrm{Na}$ ich efektywność w dużej mierze miał wpływ przebieg warunków pogodowych. W roku 2011 pierwsze chrząszcze gatunku sprężyka (A. sputator) - osiewnika skibowca odnotowano w pierwszej dekadzie maja, tj. 7 maja. Przez cały okres badawczy, odłowiono 116 osobników (rys. 2). W roku 2012, w miejscowości Łęgajny, na plantacji ziemniaka odłowiono 20 maja pierwsze chrząszcze A. lineatus - osiewnika rolowca. Najliczniej gatunek ten odławiano w drugiej dekadzie czerwca aż do pierwszej dekady lipca. Przez cały okres odłowów odłowiono 100 sztuk osobników osiewnika rolowca (rys. 2). Na tym samym polu prowadzono również monitoring drugiego gatunku A. sputator. Gatunek ten był obserwowany mniej licznie niż A. lineatus. Podobnie, jak u osiewnika rolowca, pierwsze osobniki osiewnika skibowca odłowiono 20 maja. Gatunek ten był liczniej rejestrowany w II dekadzie lipca. Najliczniej chrząszcze osiewnika rolowca odławiano 31 maja i 27 czerwca. W przypadku obu gatunków, począwszy od 24 lipca do końca lipca odnotowano ich najmniejszą liczebność. W sumie od maja do końca lipca odłowiono 31 sztuk chrząszczy osiewnika skibowca (rys. 2).

W roku 2011 odłowiono łącznie 466 sztuk osobników A. obscurus. Najliczniej gatunek ten odławiano w trzeciej dekadzie maja i pierwszej dekadzie czerwca. Początek odłowów chrząszczy rejestrowano 10 maja (rys. 3).

W miejscowości Barczewko na plantacji ziemniaka za pomocą pułapki feromonowej, w roku 2012 monitorowano występowanie i liczebność osiewnika ciemnego $A$. obscurus. Pierwsze odłowy osobników dorosłych rejestrowano w trzeciej dekadzie maja. Łacznie przez cały okres odłowów w roku 2012 oznaczono 41 sztuk osobników tego gatunku. Najliczniej chrząszcze osiewnika ciemnego odławiano od 10 czerwca do 21 lipca (rys. 3).

Monitoring A. lineatus na plantacji kukurydzy w miejscowości Garzewko, prowadzono tylko w roku 2012. Pierwsze chrząszcze osiewnika rolowca odłowiono 20 maja. Przez cały okres odłowów oznaczono 65 sztuk osobników tego gatunku (rys. 4). Najliczniej A. lineatus odławiano od 20 maja do końca maja. Spośród trzech obserwowanych gatunków, tj. osiewnika rolowca, osiewnika skibowca i osiewnika ciemnego, najliczniej odławiano osiewnika rolowca, a najmniej licznie osiewnika skibowca. Furlan i Tóth (2007) uważają, że monitoring liczebności chrząszczy z wykorzystaniem pułapek feromonowych jest ważnym ogniwem informacji $\mathrm{w}$ integrowanych systemach uprawy ziemniaka, oceny ryzyka uszkodzeń, biologii i behawioru szkodnika. Sufyan i wsp. (2011) badając na plantacji ekologicznej ziemniaka dynamikę występowania dwóch gatunków, tj. A. lineatus i A. obscurus dodatkowo oceniali również skuteczność odławiania grupy znakowanych chrząszczy (samców) w zależności od odległości od pułapki. Można tym tłumaczyć takie rozbieżności liczebności wśród obserwowanych gatunków.

Prognozowanie szkód powodowanych przez larwy Elateridae na podstawie liczby odłowionych chrząszczy z zastosowaniem pułapek feromonowych, jak podaje wielu autorów (Neuchoff i Sufyan 2008; Erlichowski 2009; 
Mangen i wsp. 2011), należy traktować orientacyjnie dla plantacji.

Prognozowanie i kontrolowanie rozwoju populacji rolnic i larw Elateridae jest bardzo trudne, gdyż brak jest korelacji pomiędzy liczbą odławianych osobników motyli i chrząszczy a liczebnością gąsienic i larw w uprawach roślin. Z tego względu bardzo ważne jest opracowanie metod prognozowania i oceny nasilenia występowania badanych Noctuinae. Uzyskane wyniki są obiecujące i wskazują na możliwość zastosowania na szerszą skalę metody zwalczania rolnic z wykorzystaniem sum ciepła i sum temperatur efektywnych po wyznaczeniu krytycznego dnia lotu motyli za pomocą samołówki.

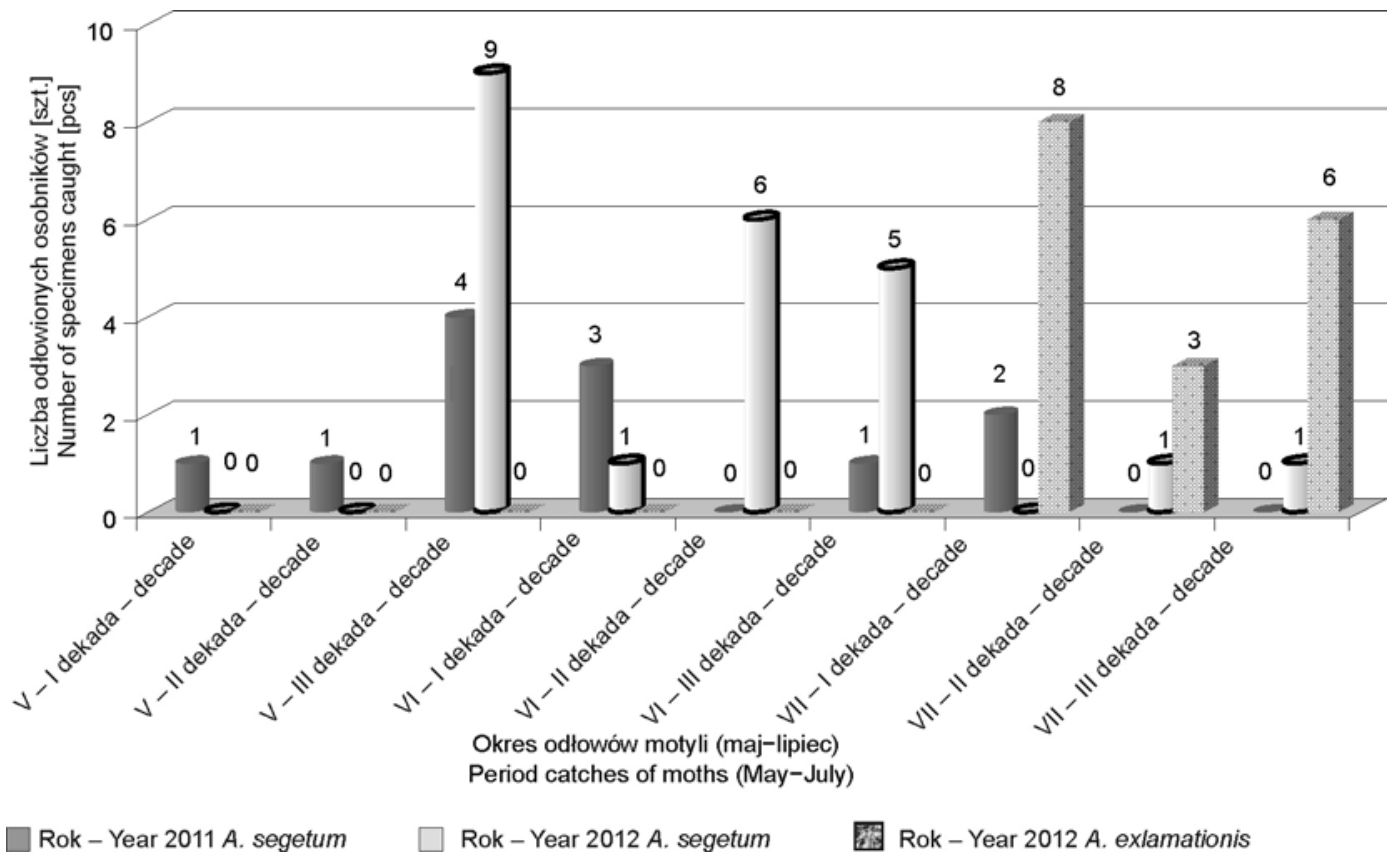

Rys. 1. Liczba odłowionych osobników A. segetum i A. exclamationis za pomocą pułapek feromonowych na plantacji kukurydzy, Garzewko 2011-2012

Fig. 1. Number of individuals of $A$. segetum and A. exclamationis caught using pheromone traps in corn plantation, Garzewko 2011-2012

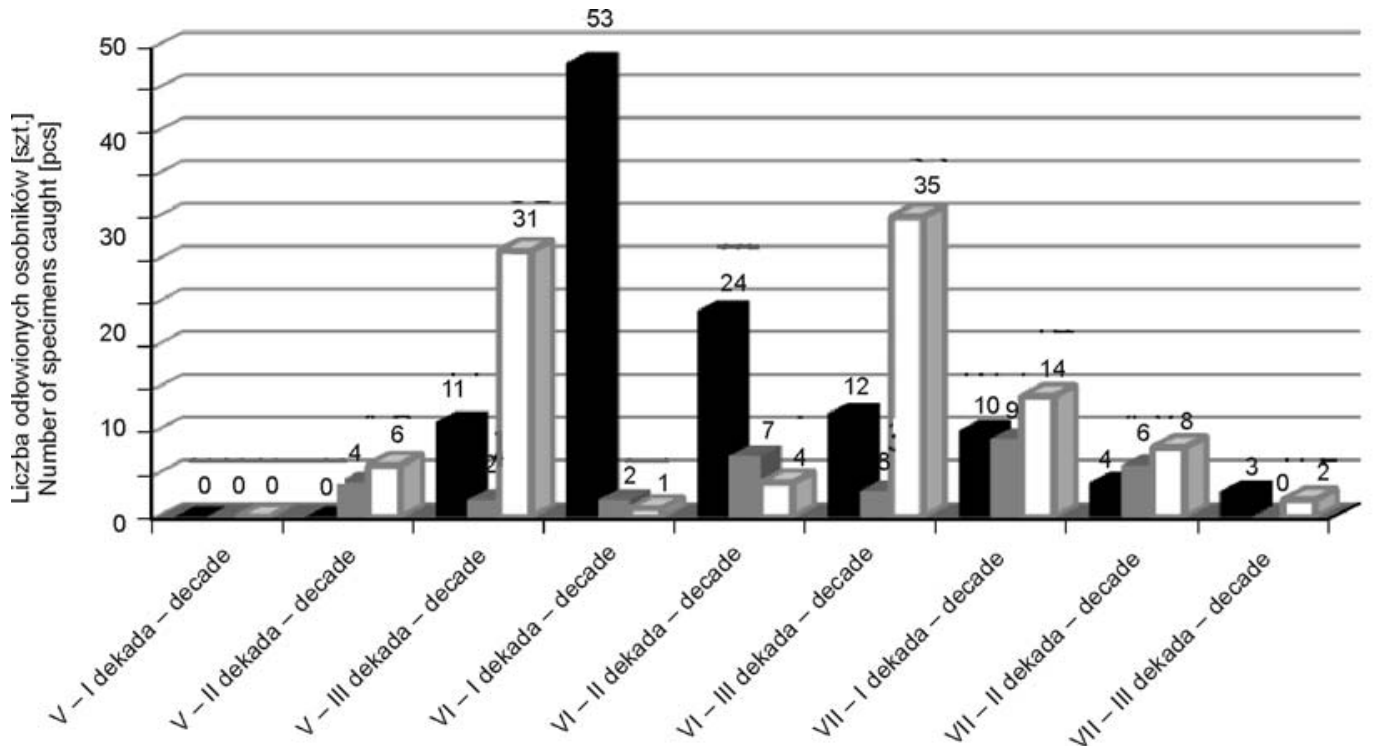

Okres odłowów sprężyków (maj-lipiec) Period catches of click beetles (May-July)

Rok - Year 2011 A. sputator

Rok - Year 2012 A. sputator

Rys. 2. Liczba odłowionych osobników A. sputator i A. lineatus za pomocą pułapek feromonowych na plantacji ziemniaka, Łęgajny 2011-2012

Fig. 2. Number of individuals of A. sputator and A. lineatus caught using pheromone traps in potato plantation, Łęgajny 2011-2012 


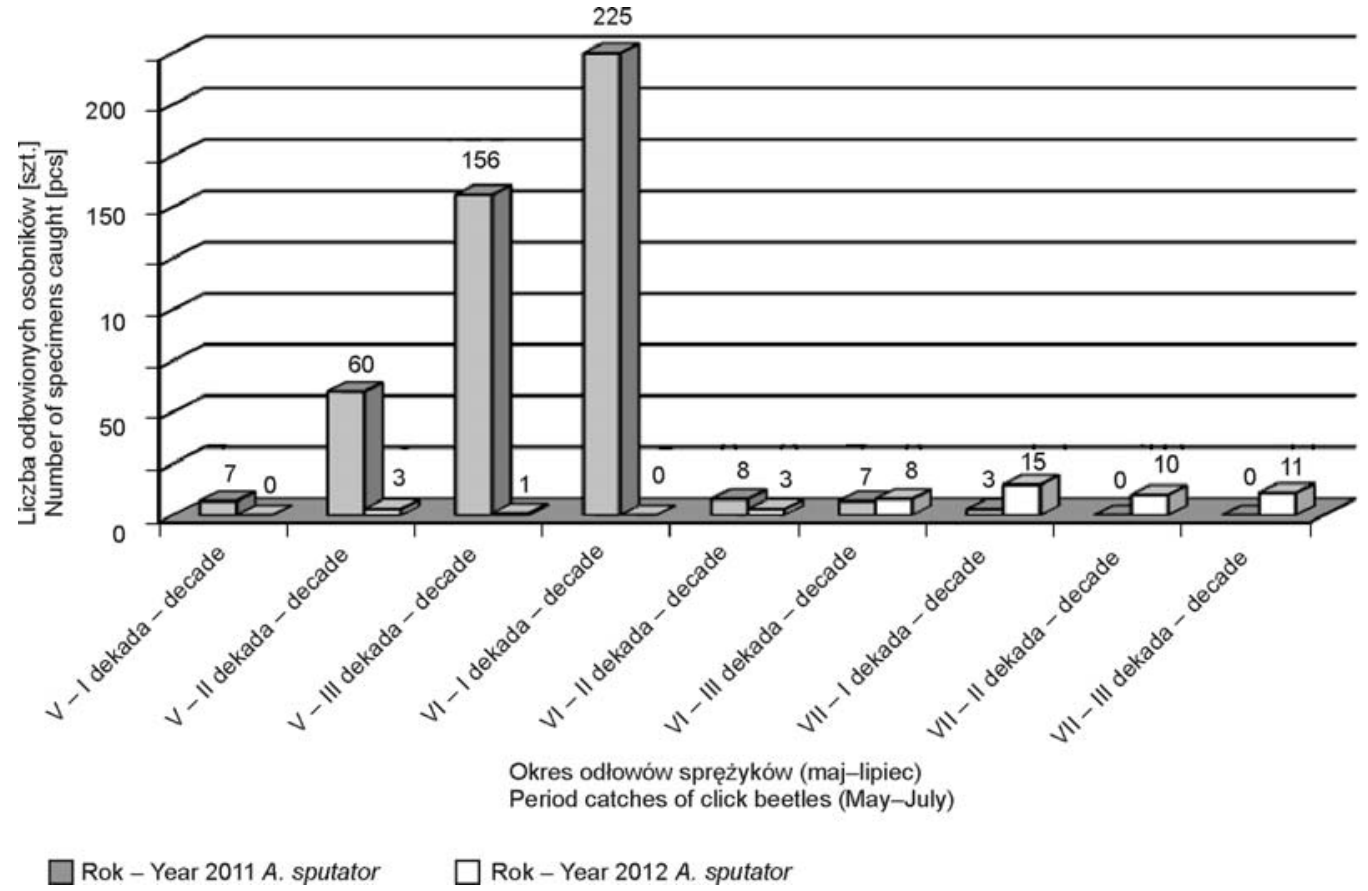

Rys. 3. Liczba odłowionych osobników A. obscurus za pomocą pułapek feromonowych na plantacji ziemniaka, Barczewko 2011-2012 Fig. 3. Number of individuals of A. obscures caught using pheromone traps in potato plantation, Barczewko 2011-2012

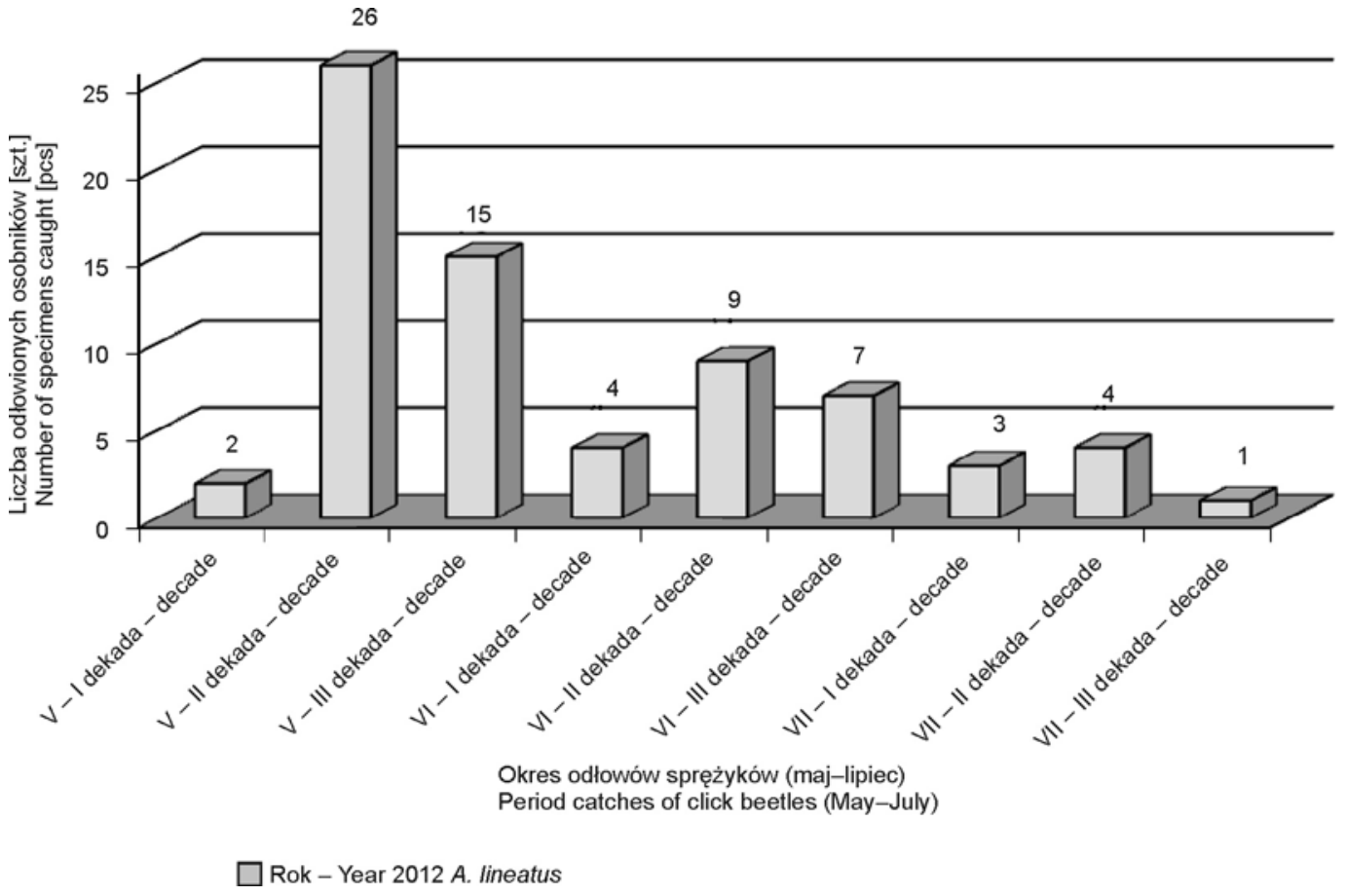

Rys. 4. Liczba odłowionych osobników A. lineatus za pomocą pułapek feromonowych na plantacji kukurydzy, Garzewko 2012

Fig. 4. Number of individuals of A. lineatus caught using pheromone traps in corn plantation, Garzewko 2012

\section{Wyniki badań nad zasiedleniem gleb przez larwy Elateridae i inne gatunki szkodników glebowych w latach 2011-2012 - analizy glebowe}

Populację Elateridae odłowionych za pomocą odkrywek glebowych, w trzech badanych miejscowościach, na terenie województwa warmińsko-mazurskiego stanowiły głównie formy larwalne (95,5\%). Rozkład gatunków sprężykowatych i ich liczebność w badanych miejscowościach były zróżnicowane i związane głównie z panującymi warunkami agrotechnicznymi. W sezonie wegetacyjnym 2012 roku wykonano 3 odkrywki glebowe, jedna wiosną i dwie w pełni wegetacji. Analiza wykazała występowanie drutowców trzech głównych gatunków występujących na ziemniakach (tab. 1). We wszystkich 
Tabela 1. Struktura ilościowa larw sprężykowatych (Elateridae) w Garzewku, Barczewie, Łęgajnach (powiat olsztyński) w latach 2011 i 2012

Table 1. The quantitative structure of wireworms (Elateridae) in Garzewko, Barczewo, Łeggajny (Olsztyn district) in the years 2011-2012

\begin{tabular}{|c|c|c|c|c|c|c|}
\hline \multirow{3}{*}{$\begin{array}{l}\text { Analizy glebowe } \\
\text { Soil sampling }\end{array}$} & \multicolumn{6}{|c|}{$\begin{array}{c}\text { Liczba odłowionych larw sprężykowatych w badanych miejscowościach [szt.] } \\
\text { Number of wireworm larvae in the study localities [pcs] }\end{array}$} \\
\hline & \multicolumn{2}{|c|}{ Garzewko } & \multicolumn{2}{|c|}{ Barczewko } & \multicolumn{2}{|c|}{ Łęgajny } \\
\hline & 2011 & 2012 & 2011 & 2012 & 2011 & 2012 \\
\hline Wiosna - Spring & $0^{*}$ & 7 & 1 & 8 & 5 & 8 \\
\hline $\begin{array}{l}\text { Pełnia sezonu } \\
\text { wegetacyjnego } \\
\text { Mid-growing season }\end{array}$ & 0 & 3 & 6 & 1 & 2 & 1 \\
\hline Jesień - Autumn & 0 & 1 & 1 & 2 & 0 & 1 \\
\hline
\end{tabular}

*odłowione larwy pochodziły od różnych gatunków - caught larvae were from different species

badanych stanowiskach dominował osiewnik ciemny, drugim licznym gatunkiem był ponęc lśniący. Odłowiono najwięcej larw A. obscurus - około $4 \mathrm{szt} . / \mathrm{m}^{2}$, a także Selatosomus aeneus L. - $2 \mathrm{szt} . / \mathrm{m}^{2}$. Ponadto odłowiono drutowce, takich gatunków, jak: Agrypnus murinus L., A. sputator, A. obscurus i Hemicrepidius niger L. Mniej licznie odnotowano występowanie larw gatunku podrzut myszaty. Jak podaje Erlichowski (2006) za Tarnawskim (2000), ostatni gatunek $\mathrm{w}$ związku $\mathrm{z}$ tym, iż nie jest szkodnikiem, powinien być traktowany jako gatunek pożyteczny - żywiący się głównie larwami i poczwarkami innych gatunków.

W roku 2011 zgodnie z przyjętą metodyką, analizy glebowe wykonano 3 razy w sezonie wegetacyjnym: na początku sezonu wegetacyjnego - 5 maja, w pełni sezonu - latem oraz pod koniec wegetacji we wrześniu. Średnie zagęszczenie populacji drutowców na wiosnę wynosiło 4-6 sztuk osobników na $1 \mathrm{~m}^{2}$. Jesienią wynosiło ono 1,5 drutowca na $\mathrm{m}^{2}$, łącznie ze wszystkich kontrolowanych pól. Populację stanowiły głównie takie gatunki, jak: Selatosomus aeneus, Athos subfuscus Müll., Agriotes atterrimus L. i Dalopius marginatus L. W przypadku gąsienic rolnic nie stwierdzono ich obecności.

\section{Wnioski / Conclusions}

1. Zaobserwowano dwa maksima lotu motyli u obu badanych gatunków. Dla rolnicy zbożówki szczyt lotu owadów dorosłych przypadł od końca maja do końca czerwca, a dla rolnicy czopówki od pierwszej dekady lipca do końca lipca. Wykorzystując omawianą metodę można w prosty sposób monitorować liczebność owadów dorosłych rolnic i w precyzyjny sposób wyznaczyć najbardziej optymalny termin zwalczania szkodników.

2. Skuteczność odławiania chrząszczy sprężykowatych przy wykorzystaniu pułapek feromonowych w poszczególnych miejscowościach była zróżnicowana. Na ich efektywność w dużej mierze miał wpływ przebieg warunków pogodowych. Spośród trzech obserwowanych gatunków, tj. osiewnika rolowca (A. lineatus), osiewnika skibowca (A. sputator) i osiewnika ciemnego (A. obscurus), najliczniej odławiano osiewnika rolowca, a najmniej licznie osiewnika skibowca.

3. W latach badań 2011-2012 wykonano 3 razy odkrywki glebowe, wiosną i dwie w pełni wegetacji. Analiza wykazała występowanie drutowców, trzech głównych szkodników występujących na plantacji ziemniaka. We wszystkich badanych stanowiskach dominował osiewnik ciemny (A. obscurus), drugim licznym był zaciosek kruszcowy (S. aeneus). Mniej licznie odnotowano występowanie larw gatunku podrzut myszaty (Agrypnus murinus).

\section{Literatura / References}

Adamczewski S.F. 1992. Zagadnienia migratyzmu u motyli (filogenetyczne i etologiczne uwarunkowania wędrówek motyli i ich ukształtowanie w środowisku różnych biomów). Warszawa, 126 ss.

Bereś P. 2011. Występowanie oraz szkodliwość rolnic (Agrotinae) dla kukurydzy (Zea mays L.) w południowo-wschodniej Polsce w latach 2004-2010. [Occurrence and harmfulness of cutworms (Agrotinae) for maize (Zea mays L.) in south-eastern Poland in 2004-2010]. Prog. Plant Prot./Post. Ochr. Roślin 51 (2): 593-598.

Boczek J. 1988. Nauka o szkodnikach roślin uprawnych. Wydawnictwo SGGW, Warszawa, 432 ss.

Burakowski B., Mroczkowski M., Stefańska J. 1985. Chrząszcze (Coleoptera) Buprestoidea, Elateroidea, Cantharoidea. Katalog Faunistyczny Polski. PWN, Warszawa 23 (10), 401 ss.

Buszko J. 1956. Klucze do oznaczania owadów Polski. Warszawa-Wrocław, PWN, Warszawa 27 (53-f): 2-41.

Buszko J. 1959. Klucze do oznaczania owadów Polski. Warszawa-Wrocław, PWN, Warszawa 27 (53-g): 2-47.

Buszko J. 1970. Klucze do oznaczania owadów Polski. Warszawa-Wrocław, PWN, Warszawa 27 (53-j): 2-53. 
Buszko J., Nowacki J. 1990. Łowność sówkowatych (Lepidoptera: Noctuidae) na światło i przynętę pokarmową w zależności od temperatury i wilgotności powietrza. Wiad. Entomol. 9: 13-20.

Buszko J., Nowacki J. 1991. Aktywność zimowa sówkowatych (Lep. Noctuidae). Wiad. Entomol. 10: 35-41.

Erlichowski T. 2006. Skład gatunkowy oraz szkodliwość fitofagicznych larw chrząszczy z rodziny sprężykowatych (Col. Elateridae) w uprawach ziemniaka - zlokalizowanych w okolicach Bonina. [The species composition and harmfulness beetle larvae of the Elateridae family (Col. Elateridae) in potato crops - located near the Bonin]. Prog. Plant Prot./Post. Ochr. Roślin 46 (2): $409-412$.

Erlichowski T. 2007. Nowe metody monitorowania i zwalczania szkodników glebowych (ze szczególnym uwzględnieniem drutowców - Elateridae) w uprawach ziemniaka. Wieś Jutra 2 (103): 1-3.

Erlichowski T. 2008. Znaczenie gospodarcze oraz czynniki warunkujące rozwój i szkodliwość szkodników glebowych w uprawie ziemniaka. Wieś Jutra 2 (119): 1-3.

Erlichowski T. 2009. Nowe metody wykrywania obecności sprężykowatych (Coleoptera: Elateridae) w uprawach ziemniaka $\mathrm{z}$ wykorzystaniem pułapek przynętowych i feromonowych. [New methods for detecting the presence of Elateridae (Coleoptera: Elateridae) in potato crops using pheromone and bait traps]. Prog. Plant Prot./Post. Ochr. Roślin 49 (4): 1691-1696.

Fibiger M. 1997. Noctuidae Europeaea vol. 3. Noctuinae III. Genitalian and supplement to Noctuinae. Entomological Press, Sorø, $418 \mathrm{pp}$.

Furlan L., Tóth M. 2007. Occurrence of click beetle pest spp. (Col., Elateridae) in Europe as detected by pheromone traps: survey results of 1998-2006. IOBC/WPRS Bull. 30 (7): 19-25.

Jakubowska M. 2008. Występowanie szkodników glebowych w burakach cukrowych na plantacjach przemysłowych w latach 2005-2007. [The occurrence of soil pests in sugar beet plantation industry in the years 2005-2007]. Prog. Plant Prot./Post. Ochr. Roślin 48 (2): 854-858.

Jakubowska M. 2009. Doskonalenie prognozowania krótkoterminowego chemicznej ochrony buraka cukrowego przed Agrotis segetum (Den. et Schiff.) i A. exclamationis (L.) (Lepidoptera: Noctuidae). Praca doktorska. Inst. Ochr. Roślin - PIB, Poznań, 176 ss.

Jakubowska M., Ławiński H. 2011. Przydatność wyników monitoringu rolnic (Agrotis sp.) na plantacjach buraka cukrowego dla potrzeb ochrony roślin. [The usefulness of the results of monitoring cutworms (Agrotis sp.) on the plantations of sugar beet in order to protect plants]. Prog. Plant Prot./Post. Ochr. Roślin 51 (2): 570-576.

Kowalska T. 1964. Effect of photoperiod and temperature on the growth of owlet moth Euxoa exclamationis L. and Rhyacia c-nigrum L. (Lep., Noctuidae). Ekol. Polska 14: 235-241.

Małachowska D. 1987. Metody sygnalizacji terminu zwalczania rolnicy zbożówki w Polsce. Gazeta Cukrownicza 2: 41-42.

Mangen M., Landl M., Glauninger J. 2011. Agriotes species: Comparison of species composition in pheromone trap catches with larval bait trap catches at the same site. IOBC/WPRS Bull. 66: 535-537.

Matyjaszczyk E., Tratwal A., Walczak F. 2010. Wybrane zagadnienia ochrony roślin w rolnictwie ekologicznym i integrowanej ochronie roślin. Inst. Ochr. Roślin - PIB, Poznań, 103 ss.

Merzeheevskaya O.I. 1989. Larvae of oulet moths (Noctuidae). Biology, Morphology, and Classification. Amerind Publishing Co. Pvt. Ltd., New Delhi, 420 pp.

Neuchoff D., Sufyan M. 2008. Potentials for wireworm control in organic farming. p. 297. Proc. EAPR Conference. Romania, Brasov, 6-10 July 2008, $301 \mathrm{pp}$.

Piekarczyk K. 1993. Metody sygnalizacji i prognozowania pojawu chorób i szkodników roślin. Instrukcja dla służby ochrony roślin z zakresu prognoz, sygnalizacji i rejestracji (S. Pruszyński, red.). Cz. II (1-2). Inst. Ochr. Roślin, Poznań, 400 ss.

Piekarczyk K., Małachowska D. 1993. Instrukcja dla służby ochrony roślin z zakresu prognoz, sygnalizacji i prognozowania pojawu chorób i szkodników roślin. Inst. Ochr. Roślin, Poznań: 90-131.

Rudolph K. 1974. Beitrag zur Kenntnis der Elateridenlarven der Fauna der DDR und BRD (Eine morphologisch-taxonomische Studie). Zool. Jb. Syst. Bd. 101: 1-151.

Sufyan M., Neuhoff D., Furlan L. 2011. Assessment of the range of attraction of pheromone traps to Agriotes lineatus and Agriotes obscurus. Agric. Forest Entomol. 13 (3): 313-319.

Tarnawski D. 2000. Fauna Polski/Fauna Poloniae. Elateridae - Sprężykowate (Insecta: Coleoptera). Cz. I. Polskie Towarzystwo Entomol., Warszawa, 411 ss.

Tykacz J. 1963. Poznajemy motyle. PZWS, Warszawa, 88 ss.

Walczak F. 2007. Monitoring agrofagów dla potrzeb ochrony roślin. Ochrona Roślin 9: 9-12.

Walczak F., Jakubowska M. 2001. Wzrost szkodliwości rolnic (Agrotinae) w Polsce. [The increase harmfulness of cutworms (Agrotinae) in Poland]. Prog. Plant Prot./Post. Ochr. Roślin 41 (2): 386-390. 